\title{
The effects and mechanisms of action of zearalenone in human intestinal epithelial cells
}

\author{
Valeria Cristina Bulgaru*1,2, Ionelia Ţăranu' ${ }^{1}$, Anca Dinischiotu ${ }^{2}$ \\ *corresponding author: cristina.bulgaru@ibna.ro
}

${ }^{1}$ Laboratory of Animal Biology, National Institute of Research and Development for Biology and Animal Nutrition, 077015 Balotesti, Romania;

2 Faculty of Biology, University of Bucharest, Splaiul Independentei 91-95, R-050095 Bucharest, Romania;

\section{ABSTRACT}

Fusariotoxins are fungal secondary metabolites produced mainly by Fusarium and Giberella species, zearalenone (ZEA) being one of the most widespread members of this class. Exposure to ZEA affects the health of animals and humans, predominantly by disrupting the activity of the reproductive system due to its structural resemblance to estrogen, but it also affects other systems such as the digestive, nervous and immune systems. The main route through which ZEA enters the body is by ingestion, the intestinal epithelium being the first tissue exposed to the toxin. The intestinal barrier not only has a mechanical role in defending the body, it is also able to secrete effector molecules involved in the immune and inflammatory response such as cytokines. In this in vitro study, performed on the line Caco-2, the effects of ZEA on inflammation of the intestinal epithelium were studied by quantifying gene expression and protein concentration of pro-inflammatory cytokines $I L-1 \beta$, $T N F-\alpha, I L-6$ and $I L-8$. Also, the mechanism of inflammation that ZEA can affect at intestinal level was investigated by monitoring the level of mRNA and the protein expression of the nuclear receptors NF- $\kappa B$ and Nrf- 2 . The results of this study demonstrate that ZEA has an anti-inflammatory character on human intestinal epithelial cells Caco-2, reducing the gene expression of the proinflammatory cytokines $I L-1 \beta, T N F-\alpha, I L-6, I L-8$. Also, ZEA led to a decrease in the protein concentration of IL- 6 and IL-8. The anti-inflammatory response seems to be induced by modulation of gene and protein expresion of $N F-\kappa B$ and Nrf-2 nuclear receptors.

Keywords: zearalenone, inflammation, intestinal epithelium 


\section{INTRODUCTION}

Fusariotoxins represent the largest class of mycotoxins, so far being identified over 140 of them, the most widespread being zearalenone (ZEA), deoxynivalenol (DON), nivalenol (NIV) and fumonisin B1 (FB1) (Bakker et al., 2018; Rai et al., 2020). There are studies that provide information about the effects that some fusarium mycotoxins have on human and animal health, but the existing data are too few, especially when it comes to the mechanisms of action of these contaminants (Kamle et al., 2019).

An important moment in the study of the effects of fusariotoxins occurred in the late 1980s, when vulvo-vaginitis was observed in sows that consumed food contaminated with Zearalenone (ZEA), indicating for the first time the possibility of ZEA being an endocrine disruptor (Gadzała-Kopciuch et al., 2011; Kuiper-Goodman et al., 1987). Subsequently, further studies have shown that ZEA have a disruptive activity on the reproductive system, due to its estrogenic structure, similar to that of $17 \beta$-estradiol (Rogowska et al., 2019). Later it was observed that the reproductive system is not the only one affected, ZEA producing toxic effects on other organs such as the spleen, liver and kidneys (Ben Salah-Abbès et al., 2020; Yordanova et al., 2003). ZEA is a resolcyclic acid lactone that has high stability and increased resistance to physical factors such as temperature and UV radiation (Zhou et al., 2020).

ZEA contaminates the human and animal body mainly orally by ingestion of grain-based food and feed or products derived from animals that eat contaminated feed. In the body, ZEA is metabolized mainly in the intestine and liver, resulting in metabolites that may be more toxic than the mycotoxin itself: $\alpha$-zearalenol $(\alpha$-ZOL), $\beta$-zearalenol $(\beta$-ZOL), $\alpha$-zearalanol $(\alpha$-ZAL), $\beta$-zearalanol ( $\beta$-ZAL) etc (Busk et al., 2011). It is estimated that the bioavailability of ZEA is over $80 \%$, being rapidly absorbed by mammals such as humans, pigs, rats and rabbits (Bulgaru et al., 2021).

The main site of absorption of ZEA, as in the case of most xenobiotics, is the intestine, which is also the body's first defence barrier. The intestinal epithelium is not only a physical barrier, its role being much more complex. The intestine also participates in the immune defence, being able to excrete effector molecules such as cytokines, triggering the immune and inflammatory response (Vancamelbeke \& Vermeire, 2017).

The Caco-2 (human colon carcinoma) cell line is widely used as a study model for the intestinal epithelial barrier. One of the most important properties of this cell line is represented by its ability to form a monolayer of cells that has many functional and structural similarities with the intestine. Caco-2 have been used in in vitro tests since 1970, the initial purpose was to study the mechanism of cancer and the development of methods for prevention, treatment and diagnosis of this disease. However, it has been found that on the cell surface there are receptors for most enzymes present in the gastrointestinal tract, the 
research being extended to the point where Caco-2 has become the most widely used in vitro model of the intestinal barrier (Lea, 2015).

There are studies that use the Caco-2 cell line as a model to investigate the metabolism, transfer and biotransformation of ZEA, the results suggesting that intestinal epithelium could play an important role in ZEA toxicity (Schaut et al., 2008; Videmann et al., 2008). Cirlini et al. studied the intestinal absorption of ZEA metabolites using the same model, demonstrating that ZEA and its metabolites are absorbed inside cells, penetrating the cell membrane . (Cirlini et al., 2016). Abdid-Essefi also reported that exposure of the Caco-2 line to ZEA can alter the cell cycle, reducing cell viability, inhibiting protein synthesis and inducing oxidative stress (Abid-Essefi et al., 2004; Halbin et al., 2005). However, further studies are needed to investigate the underlying mechanisms that ZEA triggers in the gut.

As previously mentioned, the intestinal epithelium, through the secretion of effector molecules, can trigger the inflammatory and immune response Regarding the inflammatory character of ZEA at intestinal level, it is known that ZEA can modulate the inflammatory response, but in what way it is still unclear, in vitro and in vivo studies indicate that the inflammatory character of ZEA is dependent on: concentration, exposure time and the type of tissue exposed.

In vitro studies indicate a dual character of ZEA, which can have both antiinflammatory and pro-inflammatory character depending on the type of cells used. There are studies showing that in peripheral blood mononuclear cells (PBMCs), ZEA has anti-inflammatory activity. ZEA $10 \mu \mathrm{M}$ for example, induced a significant decrease in TNF- $\alpha$ and IL-8 levels in swine PBMCs (Marin et al., 2010). In contrast, exposure of human placental carcinoma (BeWo) cells to low concentrations of ZEA (2-16 $\mu \mathrm{M}$ ) led to an increased IL-6 synthesis (Seyed Toutounchi et al., 2019), and in the case of murine peritoneal macrophage cells, ZEA produces a significant increase in IL-1 $\beta$ and IL-18 (Ding et al., 2018), in both cases the activity of ZEA being pro-inflammatory.

At the same time, not many details are known about the mechanisms by which ZEA modulates the inflammatory response. There are data suggesting that ZEA affects the immune response by modulating MAPK-inases such as JNK and p-38 $\alpha$ (Pistol et al., 2015). At the intestinal level, another possible mechanism for inducing the inflammatory response suggested by the literature is by modulating oxidative processes. The inflammatory and immune response may be modulated by NF- $\mathrm{BB}$ transcription factor activity, and by the antioxidant gene regulator erythroid nuclear factor NRF-2. Exposure to ZEA may be correlated with the antagonistic activity of these two nuclear receptors, but existing data are not sufficient to state with certainty that this is the mechanism by which ZEA acts (Kozieł et al., 2021; Pistol et al., 2015).

In this in vitro study, performed on the Caco2 cells, the effects of ZEA on inflammation of the intestinal epithelium were followed, by quantifying gene 
expression and protein concentration of pro-inflammatory cytokines IL-1 $\beta$, TNF- $\alpha$, IL- 6 and IL-8. At the same time, the mechanisms by which ZEA acts at the intestinal level were studied, by monitoring the level of mRNA and the protein expression of the nuclear receptors NF- $\kappa \mathrm{B}$ and Nrf- 2 .

\section{MATERIALS AND METHODS}

\section{Cell cultures and experimental design}

The experiments were performed in the Laboratory of Animal Biology (IBNA Balotești). Caco- 2 cells, passage 92, were thawed, washed with complete medium and cultured in T125 flasks. Once at the confluence, they were removed from the wall of the culture vessel using a trypsin-EDTA (Sigma) mixture. The recovered cells were counted using a Neubauer counting chamber and cultured in 3 experimental series. The cells were maintained in culture in 24-well plates, each well containing $2 \times 10^{5}$ cells $/ \mathrm{ml}$.

The cells were maintained in culture at a temperature of $37^{\circ} \mathrm{C}$, in an atmosphere enriched with $5 \% \mathrm{CO}_{2}$. The complete culture medium was prepared using MEM medium (Sigma) supplemented with $20 \%$ fetal bovine serum (Sigma), 1\% penicillin/streptomycin (10,000 units of penicillin / $\mathrm{ml}$ and $10 \mathrm{mg}$ streptomycin/ml) and 1\% L-glutamine (Gibco BRL). The cell medium was refreshed at 2-3 days until the confluence was reached.

Cells were stimulated with $10 \mu \mathrm{g} / \mathrm{ml}$ Lipopolysaccharide (LPS) (Sigma) and a cocktail of cytokines (50ng/ml IFN- $\gamma$ (Gibco BRL), 50ng/ml TNF- $\alpha$ (Gibco BRL), $25 \mathrm{ng} / \mathrm{ml} \mathrm{IL-1 \beta}$ (Sigma)), then treated with 20mM ZEA for 24 hours. Cytokines, LPS and toxin were prepared according to the manufacturers' instructions. IFN- $\gamma$, TNF- $\alpha$, IL-1 $\beta$ and LPS were hydrated using sterile ultrapure water, and ZEA was suspended in dimethyl sulfoxide (DMSO).

The in vitro experiments resulted in three experimental groups: 1) Control (C) that did not receive any treatment, 2) Stimulated Control (LPS) that was treated with LPS and cytokine cocktail and 3) Stimulated Control + ZEA 20mM (LPS+ZEA 20Mm) which was treated with LPS, cytokine cocktail and ZEA. At the end of the experiments, samples of cell lysate and supernatant were taken for further analysis of the expression level of genes and proteins involved in inflammatory processes, using techniques such as qPCR, ELISA and Western Blot. The supernatants were transferred to $1.5 \mathrm{ml}$ Eppendorf tubes, the cell lysate samples for qPCR analysis were taken in $700 \mu \mathrm{l}$ lysis buffer (Qiazol Lysis Buffer QIAGEN GmbH, Germany), and the cell lysate samples for Western Blot analysis were obtained after enzymatic detachment of cells with trypsin and resumed in $180 \mu \mathrm{l}$ sterile water. All samples were stored at $-80^{\circ} \mathrm{C}$. 


\section{Quantification of gene expression}

The effects produced by ZEA on the gene expression of some proinflammatory cytokines such as $I L-1 \beta, T N F-\alpha, I L-6, I L-8$, but also of the $N r f-2$, $N F-\kappa B$ nuclear receptors were analyzed.

The total RNA was isolated using the Qiagen RNeasy midi kit (QIAGEN $\mathrm{GmbH}$, Germany), at the end of the isolation 1/100 ribonuclease inhibitor (RNasin ${ }^{\circledR}$ Plus RNase Inhibitor Promega Corp., USA) was added to maintain RNA integrity. The cells were lysed using the Qiazol Lysis Buffer solution (Qiagen RNeasy midi kit), $140 \mu \mathrm{l}$ chloroform was added to the lysate obtained. The mixture was stirred vigorously for 15 seconds, incubated at room temperature for 3 minutes and centrifuged for 15 minutes at $12000 \mathrm{~g}$ and $4{ }^{\circ} \mathrm{C}$. After centrifugation the upper phase containing tRNA was transferred to $1.5 \mathrm{ml}$ tubes. $525 \mu \mathrm{l}$ of $100 \%$ ethanol were added over this aqueous phase, the mixture obtained being deposited on the RNeasy Mini purification columns and centrifuged for 15 seconds at $8000 \mathrm{~g}$. The membranes of the colonies were washed 3 times with the RWT and RPE ethanol solutions provided by the kit, and then $50 \mu \mathrm{l}$ RNase-free water was added.

To test the integrity of the isolated RNA, the samples were analysed using the Agilent 4150 TapeStation bioanalyzer and the kit provided by Agilent. $1 \mu \mathrm{l}$ of RNA Ladder was pipetted into $5 \mu$ l RNA Sample Buffer, all samples being similarly prepared. The mixture was denatured for 3 minutes at $72^{\circ} \mathrm{C}$, then incubated at $-20^{\circ} \mathrm{C}$ for 2 minutes and stirred vigorously for 1 minute. RNA ScreenTape, RNA Ladder and samples were inserted in the special support of the device, the results being obtained with the help of Agilent Tape Station Controller software.

Subsequently, the RNA samples were transcribed into complementary DNA(cDNA) using the M-MLV Reverse Transcriptase Kit (Life Technologies, Carlsbad, CA, USA) according to the manufacturer's instructions: 1000ng of RNA, $2 \mu \mathrm{l}$ OligodT and $2 \mu \mathrm{l}$ dNTP were diluted in water to a final volume of 26 $\mu \mathrm{l}$ and incubated for 5 minutes at $65^{\circ} \mathrm{C}$. A mixture of $8 \mu \mathrm{l} 5 \mathrm{x}$ Reaction Buffer and $4 \mu \mathrm{l}$ DTT was added, followed by a 2 minute incubation at $37^{\circ} \mathrm{C}$. The last step of reverse transcription was the addition of $2 \mu \mathrm{l}$ of M-MLV polymerase, incubation at $37^{\circ} \mathrm{C}$ for 50 minutes and $70^{\circ} \mathrm{C}$ for 15 minutes, the final volume was $40 \mu \mathrm{l}$.

The Rotor-Gene-Q system (QIAGEN $\mathrm{GmbH}$ ) was used to evaluate the gene expression of the pro-inflammatory cytokines $I L-1 \beta, T N F-\alpha, I L-6, I L-8$, but also of the nuclear receptors $N r f-2, N F-\kappa B$ (QIAGEN GmbH , Germany). In the reaction were mixed: $10 \mathrm{ng}$ cDNA sample, $10 \mu \mathrm{l}$ SYBR Green qPCR Master Mix (Life Technologies, Carlsbad, CA, USA), $0.3 \mu \mathrm{M}$ primers for the genes of interest and nuclease-free water (up to the final volume of $20 \mu \mathrm{l}$ ). The nucleotide sequences of the primers used in these experiments are shown in Table 1 . The reaction steps were as follows: $50^{\circ} \mathrm{C}$ for 2 minutes; $95^{\circ} \mathrm{C}$ for 10 minutes; 40 
cycles of $95^{\circ} \mathrm{C}$ for 15 seconds and $60^{\circ} \mathrm{C}$ for 60 seconds, and a final elongation at $72^{\circ} \mathrm{C}$ for 10 minutes.

Data were normalized with NormFinder software, selecting two reference genes from a total of 4 genes analysed. The results were expressed as Fold Change(FC) compared to the control group using the calculation method $2(-\Delta \Delta C)$.

Table 1. Nucleotide sequences of primers used in the qPCR reaction

\begin{tabular}{|c|c|c|c|c|c|c|}
\hline Gene & $\begin{array}{c}\text { Primer } \\
\text { orientation }\end{array}$ & $\begin{array}{l}\text { Primer } \\
\text { sequence }\end{array}$ & $\begin{array}{l}\text { Primer } \\
\text { Length }\end{array}$ & Tm & GC & $\begin{array}{c}\text { Amplicon } \\
\text { Length }\end{array}$ \\
\hline \multirow{2}{*}{$\begin{array}{l}\beta 2 \text { micro- } \\
\text { globulin }\end{array}$} & Fw & $\begin{array}{c}\text { GTGCTCGCGCTAC } \\
\text { TCTCTC }\end{array}$ & 19 & 60.3 & 63.16 & \multirow{2}{*}{150} \\
\hline & $\mathrm{Rv}$ & $\begin{array}{c}\text { GTCAACTTCAATG } \\
\text { TCGGAT }\end{array}$ & 19 & 52.99 & 42.11 & \\
\hline \multirow{2}{*}{ GAPDH } & Fw & $\begin{array}{c}\text { TGTGGTCATGAG } \\
\text { TCCTTCCA }\end{array}$ & 20 & 52.33 & 20 & \multirow{2}{*}{136} \\
\hline & $\mathrm{Rv}$ & $\begin{array}{c}\text { CATGGGTGTGAA } \\
\text { CCATGAGA }\end{array}$ & 21 & 51.66 & 20 & \\
\hline \multirow{2}{*}{$\beta$-Defensin } & Fw & $\begin{array}{c}\text { CTCTGTCAGCTCA } \\
\text { GCCTC }\end{array}$ & 18 & 56.77 & 61.11 & \multirow{2}{*}{279} \\
\hline & $\mathrm{Rv}$ & $\begin{array}{c}\text { CTTGCAGCACTTG } \\
\text { GCCTTCCC }\end{array}$ & 21 & 64.39 & 61.9 & \\
\hline \multirow{2}{*}{$\beta$-Actin } & Fw & $\begin{array}{c}\text { CCTGGCACCCAGC } \\
\text { ACAAT }\end{array}$ & 18 & 60 & 61 & \multirow{2}{*}{70} \\
\hline & $\mathrm{Rv}$ & $\begin{array}{c}\text { GCCGATCCACACG } \\
\text { GAGTACT }\end{array}$ & 20 & 62 & 60 & \\
\hline \multirow{2}{*}{ IL1- $\beta$} & Fw & $\begin{array}{l}\text { ACGAATCTCCGAC } \\
\text { CACCACTAC }\end{array}$ & 22 & 55.92 & 22 & \multirow{2}{*}{66} \\
\hline & $\mathrm{Rv}$ & $\begin{array}{l}\text { TCCATGGCCACAA } \\
\text { CAACTGACG }\end{array}$ & 22 & 57.7 & 22 & \\
\hline \multirow{2}{*}{ TNF- $\alpha$} & Fw & $\begin{array}{c}\text { TCTCGAACCCCGA } \\
\text { GTGACAA }\end{array}$ & 20 & 54.97 & 20 & \multirow{2}{*}{124} \\
\hline & $\mathrm{Rv}$ & $\begin{array}{c}\text { TATCTCTCAGCTC } \\
\text { CACGCCA }\end{array}$ & 20 & 54.5 & 20 & \\
\hline \multirow{2}{*}{ IL-6 } & $\mathrm{Fw}$ & $\begin{array}{l}\text { AAGCCAGAGCTG } \\
\text { TGCAGATGAGTA }\end{array}$ & 24 & 64 & 50 & \multirow{2}{*}{150} \\
\hline & $\mathrm{Rv}$ & $\begin{array}{c}\text { TGTCCTGCAGCCA } \\
\text { CTGGTTC }\end{array}$ & 20 & 63 & 60 & \\
\hline \multirow{2}{*}{ IL-8 } & Fw & $\begin{array}{c}\text { ACACTGCGCCAAC } \\
\text { ACAGAAATTA }\end{array}$ & 23 & 61.55 & 43.48 & \multirow{2}{*}{185} \\
\hline & $\mathrm{Rv}$ & $\begin{array}{c}\text { TTTGCTTGAAGTT } \\
\text { TCACTGGCATC }\end{array}$ & 24 & 60.74 & 41.67 & \\
\hline \multirow{2}{*}{ NF-кB } & Fw & $\begin{array}{l}\text { ACTGTGAGGATG } \\
\text { GGATCTGC }\end{array}$ & 20 & 59 & 55 & \multirow{2}{*}{165} \\
\hline & $\mathrm{Rv}$ & $\begin{array}{c}\text { GCACCAAGAGTCC } \\
\text { AGGATTA }\end{array}$ & 20 & 57 & 50 & \\
\hline \multirow{2}{*}{ Nrf-2 } & Fw & $\begin{array}{c}\text { CTACTCGTGTGGG } \\
\text { ACAGCAA }\end{array}$ & 20 & 59.68 & 55 & \multirow{2}{*}{143} \\
\hline & $\mathrm{Rv}$ & $\begin{array}{c}\text { AGCAGACTCCAGG } \\
\text { TCTTCCA }\end{array}$ & 20 & 60.18 & 55 & \\
\hline
\end{tabular}




\section{Quantification of protein expression by Western Blot}

Protein expression of two signaling molecules involved in inflammation and oxidative stress Nrf-2, NF- $\mathrm{kB}$ was determined by Western Blot. The cell lysate was obtained using a modified RIPA buffer $(50 \mathrm{mM}$ Tris buffer $\mathrm{pH} 7.4$ containing $150 \mathrm{mM} \mathrm{NaCl}, 1 \%$ Nonidet P- $40,0.25 \%$ sodium deoxycholate, $0.1 \%$ SDS and a cocktail of protease inhibitors). Over the cells suspended in $180 \mu \mathrm{l}$ ultrapure water, $20 \mu \mathrm{l}$ lysis buffer was added and homogenized. The lysate was incubated on ice for 30 minutes and then centrifuged for 15 minutes at 14,000 $\mathrm{rpm}$. The supernatant was transferred to Eppendorf tubes, and the total amount of protein was subsequently determined.

A specific kit (Pierce BCA Protein Assay Kit, Thermo Fischer Scientific, USA) was used to determine the total protein concentration, the kit contained 96-well plates. To each well was added $25 \mu$ of dilute lysate (1:9) or standard and $200 \mu \mathrm{l} \mathrm{BCA}$ working reagent. The calibration curve was performed by preparing BSA standards with concentrations between $2000 \mu \mathrm{g} / \mathrm{ml}$ and $25 \mu \mathrm{g} / \mathrm{ml} \mathrm{BSA}$. After stirring for 30 seconds the plate was covered and incubated for 30 minutes at $37^{\circ} \mathrm{C}$. The plate was brought to room temperature and the absorbance was measured at a wavelength of $562 \mathrm{~nm}$ using a plate reader (SUNRISE TECAN, Austria). Concentrations were calculated using the formula resulting from the calibration curve.

An amount of $20 \mu \mathrm{g}$ of total protein was diluted in Laemli buffer with $5 \%$ $\beta$-mercaptoethanol (Bio-Rad, California, USA), denatured for 10 minutes at $100^{\circ} \mathrm{C}$, separated by $10 \%$ SDS-PAGE electrophoresis and transferred to a nitrocellulose membrane. After blocking with a powdered milk solution, the membranes were washed with a TBS $+0.1 \%$ TWEEN 20 solution, and treated with rabbit anti-Nrf-2, rabbit anti-NF- $\kappa$ B antibodies (Cell Signaling Technology, Danvers, MA, USA, diluted 1/500) and rabbit anti- $\beta$-actin (Cell Signaling Technology, Danvers, MA, USA, diluted 1/500). After washing the membranes, they were incubated for one hour with the anti-rabbit IgG HRP conjugate (Cell Signaling Technology, Danvers, MA, USA, diluted 1/2000). Membrane band detection was performed using ECL chemiluminescence substrate (Bio-Rad) and MicroChemi Imager reader (DNR Bio-Imaging Systems LTD, Israel), and the results were evaluated using GelQuant software (DNR Bio-Imaging Systems LTD, Israel). The results were expressed as arbitrary units, the expression level of Nrf- 2 and NF- $\mathrm{\kappa B}$ was reported to $\beta$-actin.

\section{Protein concentration (ELISA)}

The protein concentration in cell culture supernatants was determined for the pro-inflammatory cytokines IL- 6 and IL- 8 by the ELISA enzyme-linked immunosorbent assay. To perform this analysis, the kits produced by $R \& D$ Systems were used, using capture antibodies, detection antibodies, the standard provided in the kits. The 96 -well plate was lined with $100 \mu \mathrm{l}$ capture 
antibody and incubated overnight. The next day the plate was washed 3 times with $400 \mu \mathrm{l} /$ well wash buffer $(0.05 \%$ TWEEN20 in PBS), then saturated with $300 \mu \mathrm{l} /$ well with saturation buffer (1\% BSA in PBS) and incubated at room temperature for an hour. The plate was washed again 3 times, and the samples and standard were distributed in it and incubated for 2 hours at room temperature. The range was achieved by binary dilutions starting at a concentration of $500 \mathrm{pg} / \mathrm{ml}$. After this step, the 3 washes were repeated and $100 \mu \mathrm{l} /$ well of detection antibody diluted in dilution buffer (1\% BSA in PBS) was added, followed by a 2 hour incubation. The plate was washed again, $100 \mu \mathrm{l} /$ well streptavidin HRP (Thermo) was added and incubated for 20 minutes at room temperature. The reaction was developed using TMB substrate solution, and then stopped with $2 \mathrm{~N} \mathrm{H}_{2} \mathrm{SO}_{4}$ solution. Protein concentration was determined by measuring the optical density relative to a standard curve, using a plate reader (SUNRISE TECAN, Austria) set to $450 \mathrm{~nm}$ wavelength.

\section{RESULTS AND DISCUSSION}

\section{Optical microscopy}

Microscopy images were captured using a Nikon Eclipse Ts2R inverted microscope and MShot Image Analysis System software. As can be seen in Figure 1, Caco- 2 cells formed a heterogeneous monolayer, morphologically similar to the intestinal epithelium. In the case of LPS-treated cells, there is a tendency to increase the diameter of the vacuoles and their preponderance in the monolayer. The addition of ZEA seems to lead to a decrease in the diameter of these vacuoles, but not in their number.

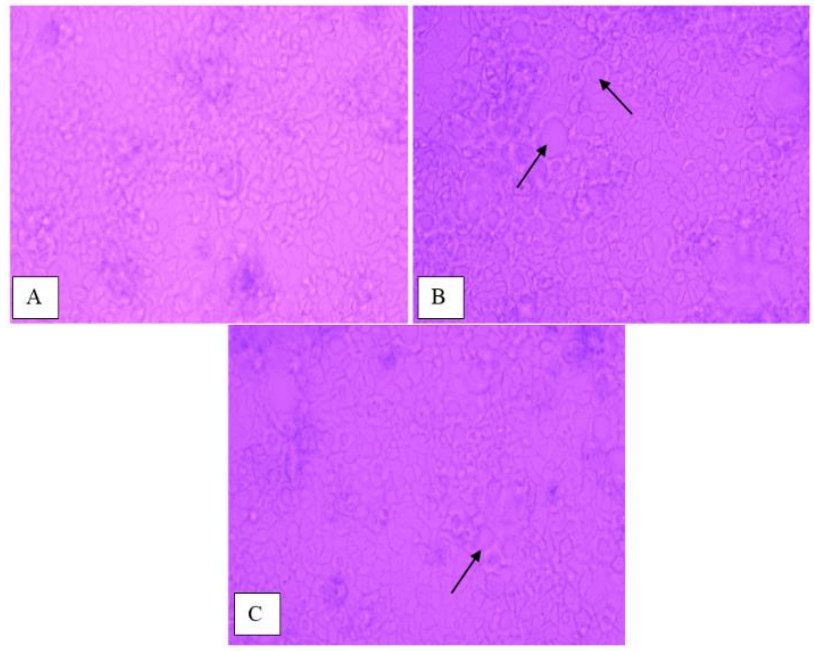

Figure 1. Microscopy images of Caco-2 cells A) Control, B) LPS Stimulated Control, C) LPS Stimulated Control + ZEA 20mM 
Quantification of gene expression encoding inflammatory markers and nuclear receptors

The integrity of RNA molecules is very important for further experiments that analyse gene expression. RNA is a thermodynamically stable molecule, which can be rapidly degraded in the presence of RNase-type enzymes. To assess the degree of degradation (integrity of isolated RNA), electrophoretic methods were applied that separate the samples according to the size of the molecules. In general, RNA integrity is assessed by the ratio of $28 \mathrm{~S}$ and $18 \mathrm{~S}$ ribosomal RNA. As can be seen in Figure 2, the extracted RNA was of superior quality, the separation of the two bands being visible, the RNA integrity number (RIN) being higher than 9.5 in the case of all samples analysed.
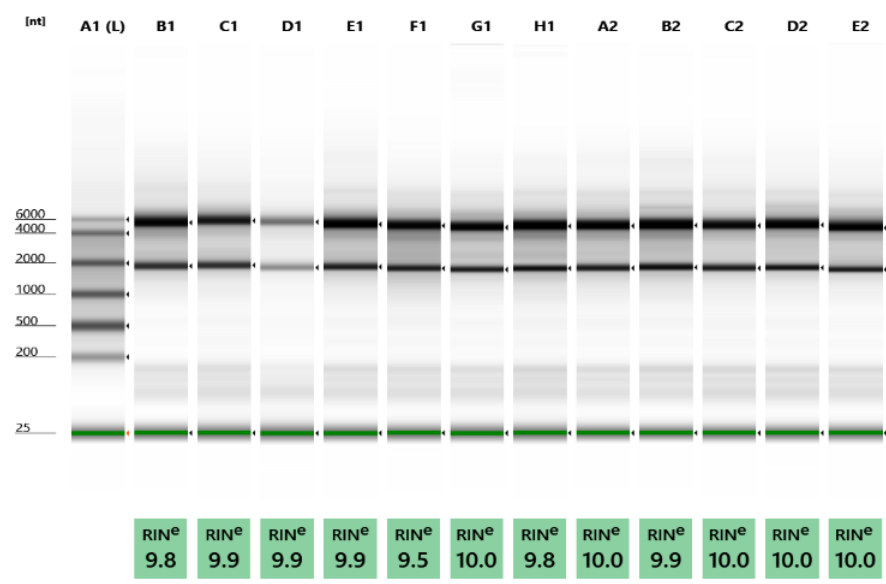

Figure 2. Assessment of extracted RNA integrity

The effects of ZEA on inflammation in the intestinal epithelium were evaluated by analyzing the gene expression of the pro-inflammatory cytokines $I L-1 \beta, T N F-\alpha, I L-6, I L-8$ (Figure 3), but also the signalling molecule involved in inflammation $N F-\kappa B$ (Figure 4 ). The results obtained showed that ZEA produces a decrease in the level of gene expression for the pro-inflammatory cytokines $I L-1 \beta, T N F-\alpha, I L-6, I L-8$ compared to untreated cells. Also, the reduction of the mRNA level for the transcription factor $N F-\kappa B$ indicates a direct involvement in the induction of ZEA toxicity. Similar results were obtained in experiments performed on other types of intestinal cells. In an IPEC-1 study, an antiinflammatory effect of ZEA was observed, cells treated with a $25 \mu \mathrm{M}$ of ZEA concentration showed a decrease in the gene expression of $I L-6, I L-8$ and TNF$\alpha$ (Braicu et al. 2016). Also, treatment of BEAS-2B epithelial lung cells with 40 $\mu \mathrm{M}$ ZEA has shown that ZEA can sensitize the immune system by decreasing the gene expression of inflammatory cytokines. The same study suggests that ZEA 
may produce an anti-inflammatory effect by inhibiting NF-kB activity via the TLR/Myd88 signalling pathway (So et al. 2014).

IL $1-\beta$

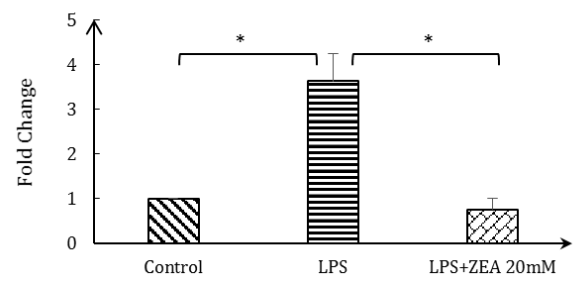

IL-6

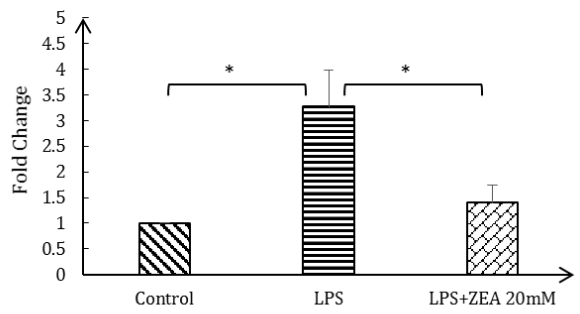

TNF- $\alpha$

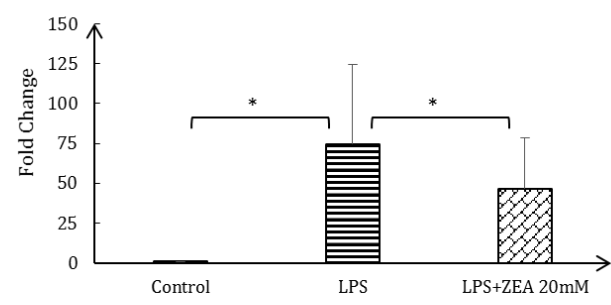

IL-8

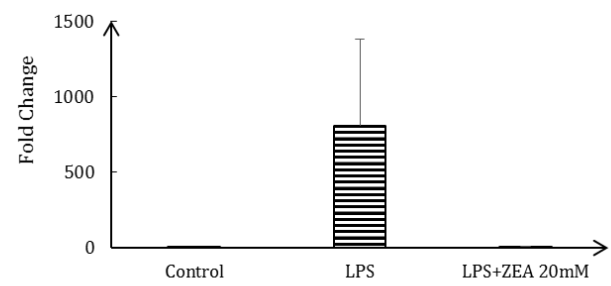

Figure 3. Gene expression of inflammatory markers under the action of ZEA

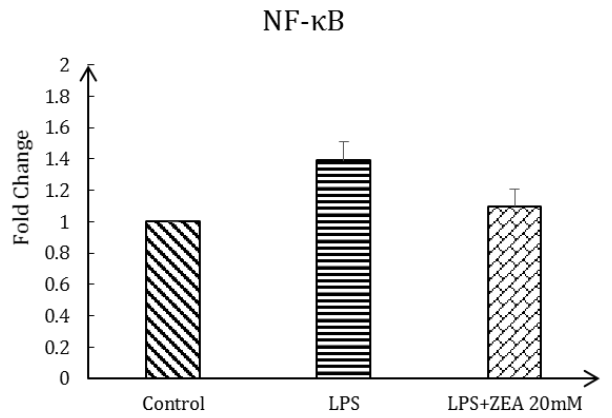

Figure 4. Gene expression of the signaling molecule involved in inflammation $N F-\kappa B$ 
Quantification of protein expression of nuclear receptors by Western Blot

The results obtained at the level of gene expression encoding for NF- $\kappa \mathrm{B}$ nuclear receptor protein, involved in the inflammatory process, were also confirmed by Western Blot analysis. Treatment with $20 \mathrm{mM}$ ZEA resulted in a decrease in the level of NF- $\mathrm{KB}$ protein expression. Moreover, the protein expression of the transcription factor Nrf-2 is affected by ZEA, which induces an increase in the level of protein expression compared to the control. The changes produced by ZEA at the level of mRNA, but also of protein expression indicate that, in the colon, ZEA could produce anti-inflammatory effects by modulating the two signalling molecules NF- $\kappa \mathrm{B}$ and Nrf-2. Results showing the ability of ZEA to modulate NF- $\kappa B$ protein expression were also obtained in a study performed on RAW264.7 cells. The treatment of RAW264.7 cells with ZEA concentrations between 1 and 100 ppm resulted in a concentration-dependent decrease in NF-kB activity (Roh et al. 2016). Based on our knowldge, the effects of ZEA on the Nrf2 protein expression in an in vitro model was not reported yet. Modulation of Nrf-2 protein expression by ZEA was reported in an in vivo study performed on post-weaning gilts. An increase in Nrf-2 protein expression was observed in the ileum and mesenteric lymph nodes of gilts treated with ZEA concentrations of $0.5-1.5 \mathrm{mg} / \mathrm{kg}$ feed (Cheng et al. 2020).
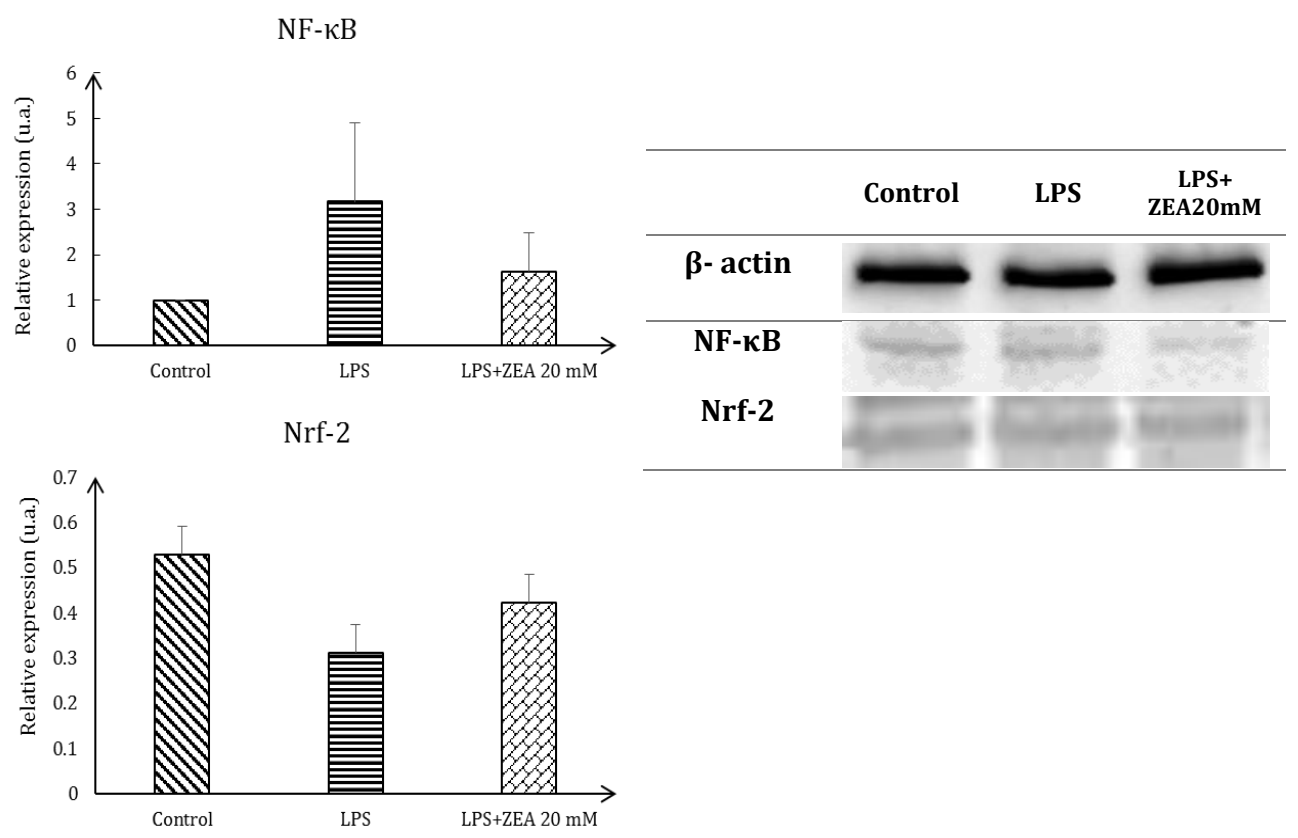

Figure 5. Protein expression of transcription factors Nrf-2 and NF-kB 
Quantification of protein concentration of cytokines IL-6 and IL-8

The protein concentration of two pro-inflammatory cytokines was determined by enzyme-linked immunosorbent assay (ELISA). The results of gene expression encoding $I L-6$ and $I L-8$ interleukins were confirmed by ELISA. As in the case of mRNA, there is a decrease in protein concentration in both IL6 and IL-8, indicating that ZEA has an anti-inflammatory character in intestinal epithelial cells.

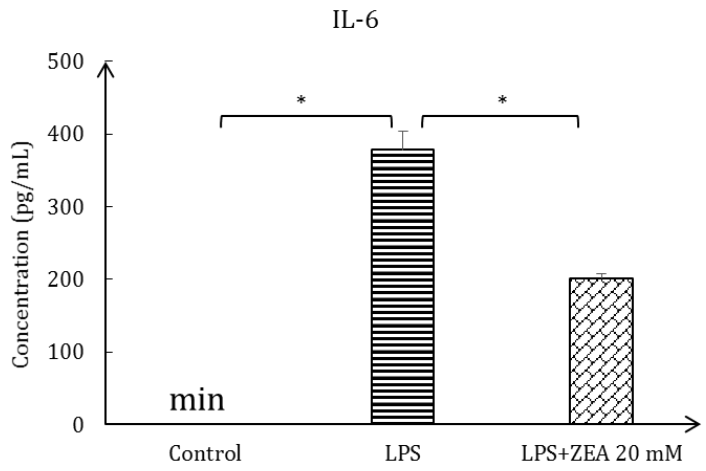

IL-8

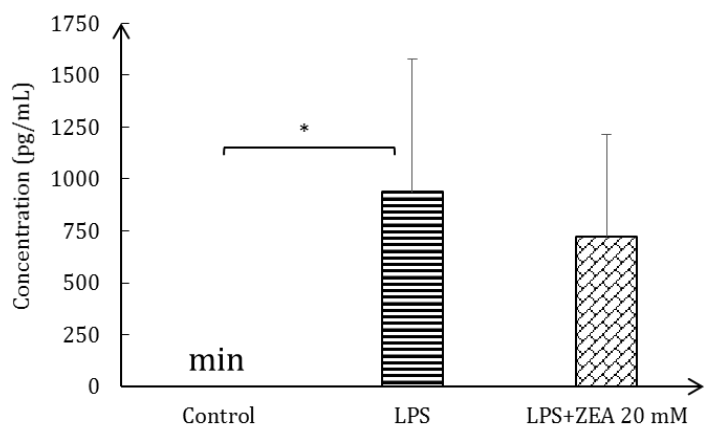

Figure 6. Protein concentration of cytokines IL-6 and IL-8

Corroborating all the data obtained from this in vitro study performed on the Caco-2 cell line, it can be assumed that ZEA has an anti-inflammatory activity leading to decreased gene expression of pro-inflammatory cytokines (TNF- $\alpha, I l-1 \beta, I L-6, I L-8)$, but also to the decrease of their protein concentration (ex. IL-6, IL-8). The main mechanism by which ZEA exerts its anti-inflammatory character being the modulation of some nuclear receptors, more precisely ZEA induces the decrease of the mRNA level and protein expression for NF-kB, an important factor in the inflammatory cascade, at the same time ZEA produces an increase of protein expression for $\mathrm{Nrf}-2$, an important regulator of antioxidant proteins. 


\section{CONCLUSION}

As the main route of exposure to this mycotoxin is oral, the first physical barrier of defense of the body is the intestine, which plays a very important role in the absorption of ZEA, and therefore its metabolism in the body.

Although derived from a colon (large intestine) carcinoma, Caco-2 cultured under specific conditions the cells become differentiated and polarized such that their phenotype, morphologically and functionally, resembles the enterocytes lining the small intestine

The results obtained showed that ZEA has an anti-inflammatory character at the level of intestinal epithelium, producing a decrease in the level of gene expression for the pro-inflammatory cytokines $I L-1 \beta, T N F-\alpha, I L-6$ and $I L-8$ compared to untreated cells, similar results being obtained in the case of protein concentrations of IL- 6 and IL-8. Also, at the intestinal level, ZEA acts by modulating the NF- $\kappa \mathrm{B}$ and Nrf-2 nuclear receptors whose expression decreased significantly for NF- $\mathrm{KB}$ and increased in the case of Nrf-2.

\section{ACKNOWLEDGEMENTS}

This research was funded by the Romanian Ministry of Agriculture and Rural Development, grant number ADER 6.2.1.

\section{REFERENCES}

Abid-Essefi, S., Ouanes, Z., Hassen, W., Baudrimont, I., Creppy, E., \& Bacha, H. (2004). Cytotoxicity, inhibition of DNA and protein syntheses and oxidative damage in cultured cells exposed to zearalenone. Toxicology in Vitro : An International Journal Published in Association with BIBRA, 18(4), 467-474. https://doi.org/10.1016/j.tiv.2003.12.011

Bakker, M. G., Brown, D. W., Kelly, A. C., Kim, H.-S., Kurtzman, C. P., Mccormick, S. P., O’Donnell, K. L., Proctor, R. H., Vaughan, M. M., \& Ward, T. J. (2018). Fusarium mycotoxins: a trans-disciplinary overview. Canadian Journal of Plant Pathology, 40(2), 161-171. https://doi.org/10.1080/07060 661.2018.1433720

Ben Salah-Abbès, Jalila, Hela Belgacem, Khawla Ezzdini, Mosaad A. AbdelWahhab, and Samir Abbès. 2020. "Zearalenone Nephrotoxicity: DNA Fragmentation, Apoptotic Gene Expression and Oxidative Stress Protected by Lactobacillus Plantarum MON03." Toxicon 175:28-35.

Bulgaru, C. v, Marin, D. E., Pistol, G. C., \& Taranu, I. (2021). Zearalenone and the Immune Response. In Toxins (Vol. 13, Issue 4). https://doi.org/10.3390/ toxins13040248

Busk, Ø. L., Ndossi, D., Verhaegen, S., Connolly, L., Eriksen, G., Ropstad, E., \& Sørlie, M. (2011). Relative quantification of the proteomic changes 
associated with the mycotoxin zearalenone in the H295R steroidogenesis model. Toxicon, 58(6), 533-542. https://doi.org/https:// doi.org/ 10.1016/j.toxicon.2011.08.015

Cavret, S., \& Lecoeur, S. (2006). Fusariotoxin transfer in animal. Food and Chemical Toxicology, 44(3), 444-453. https://doi.org/https://doi.org/ 10.1016/j.fct.2005.08.021

Cirlini, M., Barilli, A., Galaverna, G., Michlmayr, H., Adam, G., Berthiller, F., \& Dall'Asta, C. (2016). Study on the uptake and metabolism of the masked forms of zearalenone in human intestinal Caco-2 cells. Food and Chemical Toxicology, 98. https://doi.org/10.1016/j.fct.2016.11.003

Ding, J., Yeh, C.-R., Sun, Y., Lin, C., Chou, J., Ou, Z., Chang, C., Qi, J., \& Yeh, S. (2018). Estrogen receptor $\beta$ promotes renal cell carcinoma progression via regulating LncRNA HOTAIR-miR-138/200c/204/217 associated CeRNA network. Oncogene, 37(37), 5037-5053. https://doi.org/10.1038/ s41388-018-0175-6

Gadzała-Kopciuch, R., Cendrowski, K., Cesarz, A., \& Kiełbasa Pawełand Buszewski, B. (2011). Determination of zearalenone and its metabolites in endometrial cancer by coupled separation techniques. Analytical and Bioanalytical Chemistry, 401(7), 2069. https://doi.org/10.1007/s00216011-5206-x

Halbin, K., Mobio, T., Baudrimont, I., Serge, M., Dano, S., \& Creppy, E. (2005). Comparative study of cyotoxicity and oxidative stress induced by deoxynivalenol, zearalenone or fumonisin B1 in human intestinal cell line Caco-2. Toxicology, 213, 56-65. https://doi.org/10.101/j.tox.2005.05.010

Kamle, M., Mahato, D. K., Devi, S., Lee, K. E., Kang, S. G., \& Kumar, P. (2019). Fumonisins: Impact on Agriculture, Food, and Human Health and their Management Strategies. Toxins, 11(6). https://doi.org/10.3390/ toxins11060328

Kozieł, M. J., Kowalska, K., \& Piastowska-Ciesielska, A. W. (2021). Nrf2: a main responsive element in cells to mycotoxin-induced toxicity. Archives of Toxicology. https://doi.org/10.1007/s00204-021-02995-4

Kuiper-Goodman, T., Scott, P. M., \& Watanabe, H. (1987). Risk assessment of the mycotoxin zearalenone. Regulatory Toxicology and Pharmacology, 7(3), 253-306. https://doi.org/https://doi.org/10.1016/0273-2300(87) 90037-7

Lea, T. (2015). Caco-2 cell line. The Impact of Food Bioactives on Health, 103111.

Marin, D. E., Motiu, M., \& Taranu, I. (2015). Food Contaminant Zearalenone and Its Metabolites Affect Cytokine Synthesis and Intestinal Epithelial Integrity of Porcine Cells. Toxins, 7(6), 1979-1988. https://doi.org/10.3390/ toxins7061979 
Marin, D. E., Taranu, I., Burlacu, R., \& Tudor, D. S. (2010). Effects of zearalenone and its derivatives on the innate immune response of swine. Toxicon, 56(6), 956-963. https://doi.org/10.1016/J.TOXICON.2010.06.020

Oswald, I. I., Bouhet, S., Marin, D. E., Pinton, P. P., \& Taranu, I. (2003). Mycotoxin effects on the pig immune system. Feed Compounder, 09, 16-20. https://hal.inrae.fr/hal-02671003

Pistol, G. C., Braicu, C., Motiu, M., Gras, M. A., Marin, D. E., Stancu, M., Calin, L., Israel-Roming, F., Berindan-Neagoe, I., \& Taranu, I. (2015). Zearalenone Mycotoxin Affects Immune Mediators, MAPK Signalling Molecules, Nuclear Receptors and Genome-Wide Gene Expression in Pig Spleen. PLOS ONE, 10(5), e0127503. https://doi.org/10.1371/journal.pone.0127503

Rai, A., Das, M., \& Tripathi, A. (2020). Occurrence and toxicity of a fusarium mycotoxin, zearalenone. Critical Reviews in Food Science and Nutrition, 60(16), 2710-2729. https://doi.org/10.1080/10408398.2019.1655388

Rogowska, A., Pomastowski, P., Rafińska, K., Railean-Plugaru, V., Złoch, M., Walczak, J., \& Buszewski, B. (2019). A study of zearalenone biosorption and metabolisation by prokaryotic and eukaryotic cells. Toxicon, 169, 8190. https://doi.org/https://doi.org/10.1016/j.toxicon.2019.09.008

Schaut, A., de Saeger, S., Sergent, T., Schneider, Y.-J., Larondelle, Y., Pussemier, L., \& van Peteghem, C. (2008). Study of the gastrointestinal biotransformation of zearalenone in a Caco-2 cell culture system with liquid chromatographic methods. Journal of Applied Toxicology, 28(8), 966-973. https://doi.org/https://doi.org/10.1002/jat.1362

Seyed Toutounchi, N., Hogenkamp, A., Varasteh, S., van't Land, B., Garssen, J., Kraneveld, A. D., Folkerts, G., \& Braber, S. (2019). Fusarium Mycotoxins Disrupt the Barrier and Induce IL-6 Release in a Human Placental Epithelium Cell Line. In Toxins (Vol. 11, Issue 11). https://doi.org/10.3390/toxins11110665

Ünüsan, N. (2019). Systematic review of mycotoxins in food and feeds in Turkey. Food Control, 97, 1-14. https://doi.org/10.1016/J.FOODCONT. 2018.10.015

Vancamelbeke, M., \& Vermeire, S. (2017). The intestinal barrier: a fundamental role in health and disease. Expert Review of Gastroenterology \& Hepatology, 11(9), 821-834. https://doi.org/10.1080/17474124.2017.1343143

Videmann, B., Mazallon, M., Tep, J., \& Lecoeur, S. (2008). Metabolism and transfer of the mycotoxin zearalenone in human intestinal Caco-2 cells. Food and Chemical Toxicology, 46(10), 3279-3286. https://doi.org/https://doi.org/10.1016/j.fct.2008.07.011

Zhou, J., Zhu, L., Chen, J., Wang, W., Zhang, R., Li, Y., Zhang, Q., \& Wang, W. (2020). Degradation mechanism for Zearalenone ring-cleavage by Zearalenone hydrolase RmZHD: A QM/MM study. Science of The Total Environment, 709, 135897. https://doi.org/https://doi.org/10.1016/ j.scitotenv. 
2019.135897

Braicu, Cornelia, Sonia Selicean, Roxana Cojocneanu-Petric, Raduly Lajos, Ovidiu Balacescu, Ionelia Taranu, Daniela Eliza Marin, Monica Motiu, Ancuta Jurj, Patriciu Achimas-Cadariu, and Ioana Berindan-Neagoe. 2016. "Evaluation of Cellular and Molecular Impact of Zearalenone and Escherichia Coli Co-Exposure on IPEC-1 Cells Using Microarray Technology." BMC Genomics 17(1):576.

Cheng, Qun, Shuzhen Jiang, Libo Huang, Yuxi Wang, Weiren Yang, Zaibin Yang, and Jinshan Ge. 2020. "Effects of Zearalenone-Induced Oxidative Stress and Keap1-Nrf2 Signaling Pathway-Related Gene Expression in the Ileum and Mesenteric Lymph Nodes of Post-Weaning Gilts." Toxicology 429:152337.

Roh, Kyung-Baeg, Hyoyoung Kim, Seungwoo Shin, Young-Soo Kim, Jung-A. Lee, Mi Ok Kim, Eunsun Jung, Jongsung Lee, and Deokhoon Park. 2016. "AntiInflammatory Effects of Zea Mays L. Husk Extracts." BMC Complementary and Alternative Medicine 16(1):298.

Ben Salah-Abbès, Jalila, Hela Belgacem, Khawla Ezzdini, Mosaad A. AbdelWahhab, and Samir Abbès. 2020. "Zearalenone Nephrotoxicity: DNA Fragmentation, Apoptotic Gene Expression and Oxidative Stress Protected by Lactobacillus Plantarum MON03." Toxicon 175:28-35.

So, Mei Yu, ZhiPeng Tian, Yong Shian Phoon, Sha Sha, Michael N. Antoniou, JiangWen Zhang, Rudolf S. S. Wu, and Kian C. Tan-Un. 2014. "Gene Expression Profile and Toxic Effects in Human Bronchial Epithelial Cells Exposed to Zearalenone." PLOS ONE 9(5):e96404.

Yordanova, Juliana, Osvaldo A. Rosso, and Vasil Kolev. 2003. "A Transient Dominance of Theta Event-Related Brain Potential Component Characterizes Stimulus Processing in an Auditory Oddball Task." Clinical Neurophysiology: Official Journal of the International Federation of Clinical Neurophysiology 114(3):529-540. 